\title{
Polymorphisms in the 3'UTR of the human leptin gene and their role in hypertension
}

\author{
QULSUM AKHTER $^{1}$, AKBAR MASOOD ${ }^{1}$, RUHI ASHRAF ${ }^{2}$, SABIA MAJID $^{2}$, SABAH RASOOL $^{1}$, \\ TANZEELA KHAN ${ }^{1}$, TABASUM RASHID ${ }^{2}$, A. SYED SAMEER ${ }^{3}$ and BASHIR AHMAD GANAI ${ }^{1}$ \\ ${ }^{1}$ Department of Biochemistry, University of Kashmir, Hazratbal; ${ }^{2}$ Department of Biochemistry, \\ Government Medical College, Kaksarai; ${ }^{3}$ Department of Immunology and Molecular Medicine, \\ SKIMS, Soura, Srinagar, Jammu and Kashmir, India
}

Received September 10, 2011; Accepted December 12, 2011

DOI: $10.3892 / \mathrm{mmr} .2012 .743$

\begin{abstract}
Leptin is a protein hormone, mainly synthesized in adipocytes, that regulates the food intake and energy expenditure of the body. Rare mutations in the leptin gene cause obesity. Common polymorphisms of the leptin gene have been associated with obesity, however their association with arterial blood pressure has not been fully elucidated. The aim of the present study was to examine the effect of variants in the 3 flanking region of the leptin gene on blood pressure in hypertensive subjects with high $(35.2 \pm 5.12)$ and low $(20.13 \pm 1.3)$ body mass index (BMI). Microsatellite polymorphisms and the C538T SNP in the 3'UTR of the leptin gene were screened in 362 subjects, and different biochemical and anthropometric parameters were measured. The levels of serum urea, creatinine, glucose, cholesterol, triglyceride, leptin and angiotensin II were determined in all subjects. A strong association of microsatellite polymorphisms with essential hypertension was found in subjects with a high BMI, but this association was only slight in subjects with a normal BMI. The C538T variant was not found in this population. The frequency of the Class I/Class I and Class I/Class II genotype for tetranucleotide polymorphisms was also significantly higher in the hypertensive compared to the normotensive group ( $\mathrm{p} \leq 0.0001)$. In addition, a significant correlation was found between serum leptin and Class I/I and Class I/II genotypes. Linear regression analysis showed an independent correlation of leptinemia with BMI ( $p=0.019)$, while a notable correlation was found between serum leptin concentration and angiotensin II. The study confirmed that shorter alleles of microsatellites in the 3' flanking region of leptin are significantly associated with
\end{abstract}

Correspondence to: Dr Bashir Ahmad Ganai, Department of Biochemistry, University of Kashmir, Hazratbal, Srinagar, Jamuu and Kashmir 190 006, India

E-mail: mousvi786@gmail.com; bbcganai@gmail.com

Key words: essential hypertension, microsatellite, body mass index, obesity, polymorphism hypertension, however, the underlying mechanism remains unknown.

\section{Introduction}

High blood pressure is a major risk factor for cardiovascular disease. The pattern of blood pressure in western populations is such that the majority of the population is at an increasing risk for blood pressure-related cardiovascular diseases (1-5). High blood pressure has been associated with a variety of nutritional abnormalities and an increased prevalence of physical inactivity (6-8). Although some of the early studies argue against the genetic cause of hypertension $(9,10)$, several more recent ones provide evidence in favor of the genetic explanation $(11,12)$. Cloning of leptin gene and characterization of its product leptin was an important advance in the study of hormonal and metabolic alterations associated with this gene (13). Leptin is mainly produced by adipose tissue, and leptin levels are strongly and positively correlated with body mass index (BMI) $(14,15)$. However, the role of leptin deficiency in human obesity has also been considered $(16,17)$.

Previous research has demonstrated that leptin is a pleiotropic hormone with multiple actions that is potentially involved in the control of feeding, as well as in cardiovascular function, insulin secretion, angiogenesis, immune response and haematopoiesis (18). A direct effect of leptin on blood pressure has been reported (19-21), and it has been suggested that this effect is mediated by sympathetic activation (22). Moreover, a direct relationship between plasma leptin and heart rate has been observed in hypertensive patients $(20,23)$. In normotensive men, serum leptin levels were found to be related to serum angiotensin II levels (33), which has a well established role in the regulation of blood pressure. Also, a positive correlation was found between these two parameters in hypertensive subjects (34). This relationship appears to be independent of BMI, plasma insulin and physical activity. The presence of a microsatellite polymorphism in the 3'UTR of the leptin gene was found to be significantly correlated with hypertension, independent of obesity in a Japanese population (24). A similar polymorphism in the leptin gene was found in an Italian population, but no association of this polymorphism with obesity-dependent hypertension was observed (25). 
Table I. Anthropometric and laboratory data of the study subjects.

\begin{tabular}{|c|c|c|c|c|c|}
\hline Variables & $\begin{array}{c}\text { Hypertensive } \\
\text { lean }\end{array}$ & $\begin{array}{c}\text { Hypertensive } \\
\text { obese }\end{array}$ & $\begin{array}{c}\text { Normotensive } \\
\text { obese }\end{array}$ & $\begin{array}{c}\text { Normotensive } \\
\text { lean }\end{array}$ & $\begin{array}{l}\text { Sign. of } \\
\text { difference }\end{array}$ \\
\hline Age (years) & $53.00 \pm 8.35$ & $50.00 \pm 8.35$ & $43.20 \pm 8.60$ & $42.025 \pm 8.60$ & $\mathrm{p}=0.0001$ \\
\hline BMI $\left(\mathrm{kg} / \mathrm{m}^{2}\right)$ & $22.10 \pm 2.80$ & $35.20 \pm 5.12$ & $29.50 \pm 3.20$ & $21.850 \pm 1.01$ & $\mathrm{p}=0.0001$ \\
\hline Systolic blood pressure (mmHg) & $144.51 \pm 16.01$ & $145.10 \pm 15.21$ & $120.90 \pm 2.20$ & $120.500 \pm 5.75$ & $\mathrm{p}=0.0001$ \\
\hline Diastolic blood pressure (mmHg) & $92.25 \pm 10.61$ & $92.20 \pm 12.18$ & $80.50 \pm 3.20$ & $80.050 \pm 3.12$ & $\mathrm{p}=0.0001$ \\
\hline Serum creatinine $(\mathrm{mg} / \mathrm{dl})$ & $0.90 \pm 0.23$ & $1.05 \pm 0.22$ & $0.90 \pm 0.11$ & $0.920 \pm 0.25$ & $\mathrm{p}=0.4230$ \\
\hline Urea $(\mathrm{mg} / \mathrm{dl})$ & $25.75 \pm 9.39$ & $30.00 \pm 6.70$ & $31.00 \pm 10.50$ & $26.320 \pm 8.70$ & $\mathrm{p}=0.7780$ \\
\hline Cholesterol (mg/dl) & $165.00 \pm 23.80$ & $175.00 \pm 23.80$ & $172.00 \pm 19.80$ & $160.770 \pm 25.60$ & $\begin{array}{l}\mathrm{P}=0.0250 \\
\mathrm{P}^{2}=0.0470\end{array}$ \\
\hline Glucose R (mg/dl) & $98.40 \pm 22.62$ & $94.00 \pm 7.13$ & $102 \pm 14$ & $95.500 \pm 15.70$ & $\mathrm{p}=0.5070$ \\
\hline Triglycerides (mg/dl) & $165.37 \pm 21.90$ & $182.02 \pm 15.80$ & $180 \pm 23$ & $165 \pm 15.20$ & $\begin{array}{l}\mathrm{P}=0.3800 \\
\mathrm{P}^{2}=0.7170\end{array}$ \\
\hline $\mathrm{Na}^{+}$ & $144.00 \pm 5.10$ & $141.00 \pm 6.20$ & $139 \pm 5.30$ & $142 \pm 8.23$ & $\mathrm{P}=0.2020$ \\
\hline $\mathrm{K}^{+}$ & $4.50 \pm 0.46$ & $4.03 \pm 0.48$ & $4.14 \pm 0.44$ & $3.900 \pm 0.56$ & $\mathrm{P}=0.4100$ \\
\hline Leptin (ng/dl) & $11.90 \pm 3.77$ & $18.71 \pm 15.50$ & $13.82 \pm 12.63$ & $9.420 \pm 12.20$ & $\begin{array}{l}\mathrm{P}=0.0070 \\
\mathrm{P}^{2}=0.0630\end{array}$ \\
\hline Angiotensin II (ng/dl) & $1.17 \pm 1.36$ & $1.47 \pm 1.60$ & $1.34 \pm 2.20$ & $1.250 \pm 1.23$ & $\begin{array}{l}\mathrm{P}=0.9760 \\
\mathrm{P}^{2}=0.1280\end{array}$ \\
\hline
\end{tabular}

Values are presented as the means $\pm \mathrm{SD}$. P, significance between all hypertensives vs. normotensives; $\mathrm{P}^{2}$, significance between all obese vs. all lean subjects.

Another variant, the C538T in the 3'UTR of the leptin gene, was similarly shown to be associated with essential hypertension independent of obesity (26). However, in another study on an African-American group, several genetic markers at the leptin locus, including the one described by Shintani et al (24), were not significantly linked to hypertension (27). These contradictory data prompted us to investigate the presence of common tetranucleotide repeat polymorphisms and the rare C538T SNP in the 3' flanking region of the leptin gene in: hypertensive patients independent of obesity, in obese hypertensive patients and in controls. Since several hormones, such as insulin and steroids $(35,36)$, affect angiotensin mRNA, this study was designed to investigate whether leptin upregulates the activity of the gene in adipocytes, thereby contributing to hypertension.

\section{Materials and methods}

Subjects. In the present study, 362 patients with hypertension were investigated; 119 subjects were hypertensive with a BMI of $22.10 \pm 2.8$ and 155 were hypertensive with a BMI of $35.2 \pm 5.12 .88$. Normotensive subjects with different BMIs were also studied as controls. All subjects were either first time diagnosed or had not taken any medication at least 15 days prior to the study. All subjects underwent a physical examination that included measurement of the BMI (evaluated by weight $/$ height $^{2} ; \mathrm{kg} / \mathrm{m}^{2}$ ) and levels of serum urea, creatinine, billuribin, cholesterol, glucose and triglyceride. All subjects had normal thyroid function. No patient with renal, hepatic or cardiac disease was included and none of the subjects had diabetes. Therefore, only a specific group of subjects with essential hypertension was selected. After determining all the biochemical parameters and measuring other anthropometric parameters, blood was obtained from the subjects, collected in EDTA vials and stored at $-20^{\circ} \mathrm{C}$ for genomic studies. The study was approved by the local institutional ethics committee, and informed consent was obtained from all of the subjects.

Genotyping. Genomic DNA was extracted from whole blood using a commercial kit (Zymo Research Corp., Irvine, CA, USA). Genotyping of the tetranucleotide polymorphisms in the $3^{\prime}$ flanking region of the leptin gene was detected by polymerase chain reaction using forward primer 5'-AGTTCAAATAGAGGTCCAAATCA-3' and reverse primer 5'-TTCTGAGGTTGTGTCACTGGCA-3' that flanks the microsatellite in the $3^{\prime}$ flanking region of the leptin gene. Another primer pair, 5'-CGACCTGGAGAACCTCCG-3' as forward and 5'-GTCCTGGATAAGGGGTGT-3' as reverse, was used for amplification of the 316-bp amplicon in the 3'UTR of the leptin gene for the screening of the C538T variant. PCR contained $100 \mathrm{ng}$ of genomic DNA template, $0.2 \mu \mathrm{M}$ of each primer, $2 \mathrm{mM}$ of $\mathrm{Mg}^{2+}, 0.2 \mathrm{mM}$ of each dNTP, 1.5 units of Taq polymerase and $1 \mathrm{X}$ reaction buffer in a total volume of $25 \mu \mathrm{l}$. The PCR was performed for 30 cycles of $30 \mathrm{sec}$ at $94^{\circ} \mathrm{C}, 30 \mathrm{sec}$ at $55^{\circ} \mathrm{C}$ and $1 \mathrm{~min}$ at $72^{\circ} \mathrm{C}$, with an initial denaturation of $5 \mathrm{~min}$ at $94^{\circ} \mathrm{C}$ and a final extension of $10 \mathrm{~min}$ at $72^{\circ} \mathrm{C}$. The reaction conditions were the same for both pairs of primers. PCR products were run in 2\% agarose gel along with 100-bp ladder as a molecular weight marker. Amplified products were visualized by staining with ethidium bromide. In the case of the tetranucleotide repeat polymorphisms, alleles were distinguished on the basis of amplicon length, which varies for different 
Table II. Frequency of the genotypes of the leptin gene polymorphism in hypertensive and normotensive subjects.

\begin{tabular}{lccc}
\hline Variants/Genotypic distribution & Hypertensive lean & Hypertensive obese & Normotensive \\
\hline C538T & & & Total \\
C/C & 119 & 155 & Nil \\
C/T & Nil & Nil & Nil \\
T/T & Nil & Nil & $12(13.6)$ \\
Microsatellite & $53(44.5)$ & $71(45.8)$ & $362(47.7)$ \\
I/I & $41(34.4)$ & $60(38.7)$ & $34(38.6)$ \\
I/II & $25(21.0)$ & $24(15.4)$ & p $\leq 0.0001$ \\
II/II & & & 362 \\
\hline
\end{tabular}

Absolute no. (percentage) of subjects are shown.

Table III. Association of different alleles with serum leptin and serum angiotensin II levels.

\begin{tabular}{|c|c|c|c|}
\hline Microsatellite genotypes & Serum leptin (ng/dl) & Serum angiotensin II (ng/dl) & Significance \\
\hline Genotype I/I (n=26) & $19.2 \pm 6.12$ & $1.2 \pm 1.35$ & $\begin{array}{l}\mathrm{P}^{\mathrm{a}}=0.022 \\
\mathrm{P}^{\mathrm{a} 1}=0.737\end{array}$ \\
\hline Genotype I/II (n=34) & $18.7 \pm 15.2$ & $1.40 \pm 1.55$ & $\begin{array}{l}\mathrm{P}^{\mathrm{b}}=0.080 \\
\mathrm{P}^{\mathrm{a} 2}=0.640\end{array}$ \\
\hline Genotype II/II (n=24) & $16.2 \pm 12.6$ & $1.28 \pm 1.26$ & $\begin{array}{l}\mathrm{P}^{\mathrm{c}}=0.298 \\
\mathrm{P}^{\mathrm{a} 3}=0.336\end{array}$ \\
\hline
\end{tabular}

$\mathrm{P}^{\mathrm{a}}$ and $\mathrm{P}^{\mathrm{a} 1}$ show the significance between Class I/I vs. Class II/II of serum leptin and angiotensin II levels, respectively. $\mathrm{P}^{\mathrm{b}}$ and $\mathrm{P}^{\mathrm{a} 2}$ show the significance between Class I/I vs. Class I/II of serum leptin and angiotensin II levels, respectively. $\mathrm{P}^{\mathrm{c}}$ and $\mathrm{P}^{\mathrm{a} 3}$ show the significance between Class I/II vs. Class II/II of serum leptin and angiotensin II levels, respectively.

alleles due to the variable number of tetranucleotide repeats. For the screening of the C538T variant, a 316-bp fragment was digested with the HypCH4IV enzyme. The digested products were run on $8 \%$ PAGE along with pBR322MspI digest as a molecular weight marker. Ten percent of the digested samples were sequenced directly as well.

Analysis of serum leptin concentration. To study the relationship between the leptin gene polymorphism and the serum leptin concentrations, serum leptin levels were determined with the human leptin immunoassay kit (DRG International Inc., Mountainside, NJ, USA). Serum was collected from each patient in the morning. Frozen samples were kept at $-20^{\circ} \mathrm{C}$ until analysis.

Analysis of serum angiotensin II concentration. To study whether leptin upregulates the expression of angiotensin II levels, which is the main regulator of blood pressure, the serum angiotensin II concentration was determined with the angiotensin II ELISA kit (DRG International Inc.).

Statistical analysis. Data are expressed as the means \pm SD. The means were compared by the independent sample t-test. Fisher's exact test or $\chi^{2}$ test was used to compare the frequencies. Regression analysis was used to describe the relationship between serum leptin as a dependent variable, and the BMI and serum angiotensin II levels as independent variables.
Statistical analysis was carried out using the statistical package SPSS.

\section{Results}

Table I shows the characteristics of the population that was genotyped for the microsatellite polymorphisms and the C538T variant in the 3' flanking region of the leptin gene. The age of the hypertensive group ranged from 45 to 65 years (mean $\pm \mathrm{SD}, 53 \pm 8.35$ ), while the age of the control group ranged from 35 to 50 years $(42.025 \pm 8.6)$. In the hypertensive group, 168 subjects were female and 106 were male, and in the normotensive group 30 were female and 58 male. There was no statistically significant difference in the serum urea, creatinine, glucose, bilirubin, triglyceride and angiotensin II, when compared between the hypertensive vs. normotensive class, or between the obese vs. lean class $(\mathrm{p}>0.05)$. A significant correlation was found between serum leptin when compared between the hypertensive vs. normotensive class, and also between the obese and lean class $(\mathrm{p} \leq 0.05)$. Linear regression analysis showed an independent correlation of leptinemia with BMI ( $\mathrm{p}=0.019)$, but no significant correlation was found between the serum leptin concentration and angiotensin II (Table IV). Alleles of the microsatellite were composed of two groups with different size distribution; a shorter one, $<190$ bp in size (termed as Class I), and a longer one $>210 \mathrm{bp}$ in size (termed as Class II; Fig. 2). The frequency of Class I/ 
Table IV. Linear regression analysis for all subjects (HL, HO, NL and NO), obese subjects (HO and NO), and lean subjects (HL and NL).

\begin{tabular}{lcccr}
\hline Independent variables & Regression coefficients & $\begin{array}{c}\text { 95\% confidence interval of } \\
\text { regression coefficient }\end{array}$ & p-value & $\mathrm{R}^{2}$ \\
\hline BMI (HO, HL, NO, NL) & 0.255 & 0.02384 to 0.26150 & 0.019 & 0.065 \\
ANG II (HO, HL, NO, NL) & 0.171 & -0.01370 to 0.04150 & 0.120 & 0.029 \\
BMI (HO, NO) & 0.482 & $-0.06166 \pm 0.01653$ & 0.001 & 0.232 \\
ANG II (HO, NO) & 0.148 & $-0.05043 \pm 0.05405$ & 0.357 & 0.025 \\
BMI (HL, NL) & 0.167 & $0.02759 \pm 0.02397$ & 0.256 & 0.028 \\
ANG II (HL, NL) & 0.203 & -0.01253 to 0.04931 & 0.235 & 0.041 \\
\hline
\end{tabular}

Serum leptin was used as a dependent variable and body mass index (BMI), genotypic variant Class I/I and angiotensin II (ANG II) as independent variables. $\mathrm{H}$, hypertensive; N, normotensive; L, lean; O, obese. BMI, body mass index; ANG II, angiotensin II.

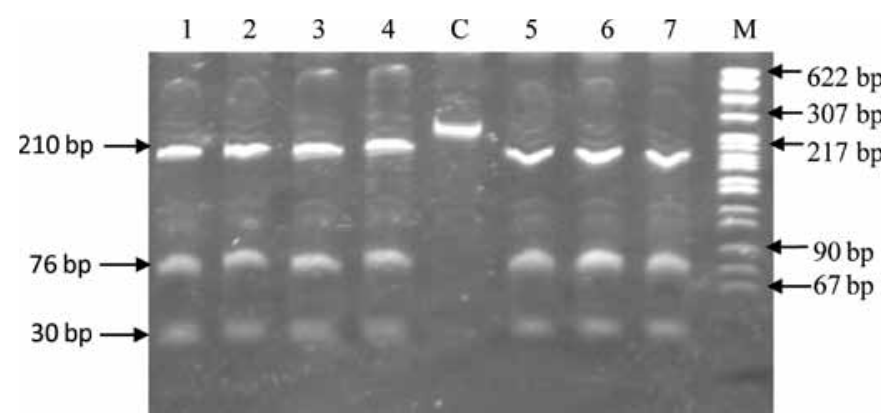

Figure 1. Representative polyacrylamide gel image (8\%) showing the results of the HpyCh4IV digested PCR product. Lanes 1-7 show the digestion pattern of different samples under evaluation [homozygous wild-type $(\mathrm{C} / \mathrm{C})$ genotypes]. Lane $\mathrm{M}$ shows the separation pattern of pBR322MspI digested DNA marker. C represents the undigested PCR product (control).

Class I genotype were higher in the hypertensive group than in the normotensive group (Table II). Class I/I and Class I/ II was found to be significantly correlated with serum leptin concentration ( $\mathrm{p} \leq 0.05)$, but no such correlation was observed with serum angiotensin II levels (Table III). In the case of the C538T variant, upon digestion with the HpyCH4IV restriction enzyme, the wild-type genotype provided three fragments of size 210, 76 and $30 \mathrm{bp}$, carriers had four fragments of size 210 , 76, 30 and $286 \mathrm{bp}$, whereas mutant homozygotes gave two bonds of size 286 and $30 \mathrm{bp}$. All 362 subjects studied showed the digestion pattern of wild-type homozygotes (Fig. 1) and direct sequencing of $10 \%$ of the subjects confirmed this.

\section{Discussion}

Obesity and essential hypertension are considered to be the result of multiple environmental and genetic determinants. These two factors are closely linked in epidemiological studies (28), and essential hypertension is estimated to be up to three times more prevalent among obese populations (29). One of the major mechanisms leading to the development of obesity-induced hypertension appears to be leptin-mediated sympatho-activation. In African-Americans, highly polymorphic markers in leptin locus were not significantly linked to the trait of essential hypertension (27). Later, several studies

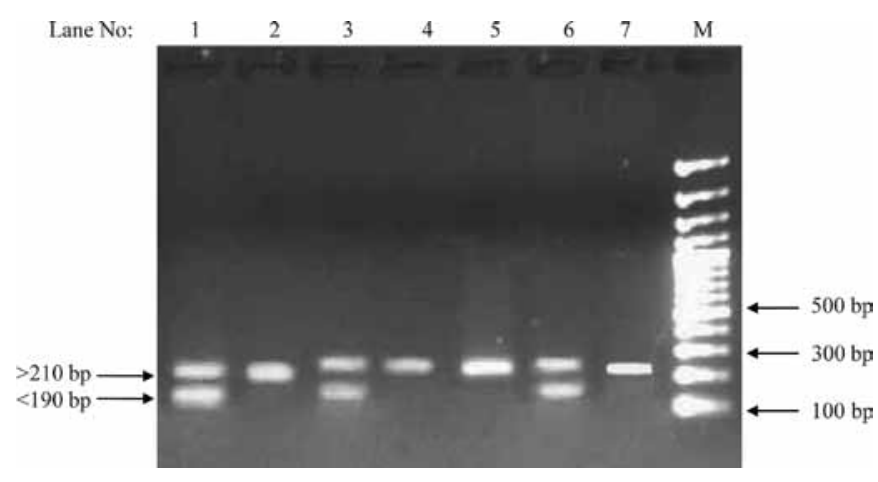

Figure 2. Representative gel image showing the PCR results. Lanes 1, 3 and 6 represent heterozygotes, and lanes 2, 4, 5 and 7 represent homozygotes for the Class II allele of the microsatellite polymorphism of the leptin gene. M, marker (100-bp ladder).

on a Japanese population showed a significant association of the polymorphism in the $3^{\prime} \mathrm{UTR}$ region of the leptin gene with hypertension, while this association was independent of BMI. In another study involving a British population, another rare variant in the 3'UTR of the leptin gene was found to impact pulse pressure considerably, independent of obesity and cortico intima-mediated thickness (26). The results of our study confirmed that the $3^{\prime}$ flanking region polymorphism of the gene previously described by Shintani et al (24) is also found in a pure ethnic population of Kashmir. A significant association of the microsatellite polymorphism with hypertension was found. Another variant, C538T, was observed to be very rare in some populations $(26,32)$, but seems to be either absent or even rarer in the Kashmiri population. However, a larger sample size is required to confirm this possibility. Although the microsatellite polymorphism examined is located in noncoding region, similarly located variants in the 3'UTR of other genes are known to play a key role in their expression $(30,31)$. There are generally some cis-acting determinants in the 3'UTR to which proteins bind and either stabilize or destabilize the mRNA. Cis-acting determinants in the 3'UTR may also interact with other sequences within that mRNA. Therefore, the variation in these cis-acting determinants may affect the expression of this particular gene. This case may be similar to the present study, as we found that serum leptin is significantly 
associated with Class I/Class I and Class I/Class II genotypes. Thus, the Class I/I and I/II genotypes were shown to be closely associated to hypertensive and serum leptin concentration. To determine whether this relation of leptin is mediated through angiotensin II, whose role in the regulation of blood pressure is well established, the concentration of angiotensin II was also assessed. However, a negative correlation was found between leptin and angiotensin II in all groups. The present data suggest that the common polymorphism in the 3 ' flanking region of the leptin gene is relative to essential hypertension. Further in vitro and animal model research is necessary to elucidate how the variation in the size of microsatellite in the 3 ' flanking region of the gene is involved in the regulation of blood pressure in obesity-dependent and obesity-independent hypertension.

\section{Acknowledgements}

This study was supported by research grants from the Department of Science and Technology, Government of India New Delhi, under the Women Scientist Scheme.

\section{References}

1. Clausen J and Jensen G: Are blood pressure levels increasing in Denmark? J Intern Med 228: 443-450, 1985.

2. Epstein FH, Francis T, Hayner NS, et al: Prevalence of chronic diseases and distribution of selected physiologic variables in a total community, Tecumseh, Michigan. Am J Epidemiol 81: 307-322, 1965

3. Ferrannini E, Haffner SM and Stern MP: Insulin sensitivity and hypertension. J Hypertension 8 (Suppl II): 3-7, 1990.

4. Kannel WB, Wilson PW and Zhang TJ: The epidemiology of impaired glucose tolerance and hypertension. Am Heart J 121: 1268-1273, 1991.

5. Webber LS, Voors AW, Srinivasan SR, Frerichs RR and Berenson GS: Occurrence in children of multiple risk factors for coronary artery disease: the Bogalusa heart study. Prev Med 8: 407-418, 1979.

6. Tuomilehto J, Zimmet P, Taylor R, Bennett P and Wolf E: A cross-sectional ecological analysis of blood pressure and its determinants in eleven Pacific populations. J Am Coll Nutr 8: 151-165, 1989.

7. Sever PS, Gordon D, Peart WS and Beighton P: Blood-pressure and its correlates in urban and tribal Africa. Lancet 2: 60-64, 1980

8. Costa Ede A, Rose G, Klein CH, et al: Salt and blood pressure in Rio Grande do Sul, Brazil. Bull Pan Am Health Organ 24: 159-176, 1990.

9. Amery A, Fagard R, Guo C, Staessen J and Thus L: Isolated systolic hypertension in elderly. JAMA 250: 70-74, 1991.

10. Frishman WH: Epidemiology, pathophysiologic, and managementof isolated systolic hypertension in the elderly. Am J Med 9 (Suppl 3A): 14-20, 1992.

11. Bonnardeaux A, Davies E, Jeunemaitre X, et al: Angiotensin II type 1 receptor gene polymorphisms in human essential hypertension. Hypertension 24: 63-69, 1994.

12. Markan S, Sachdeva M, Sehrawat DS, Kumari S, Jain S and Khullar M: MTHFR 677 CT/MTHFR 1298 CC genotypes are associated with increased risk of hypertension in Indians. Mol Cell Biochem 302: 125-131, 2007.

13. Zhang Y, Proenca R, Maffei M, Barone M, Leopold L and Friedman JM: Positional cloning of the mouse obese gene and its human homologue. Nature 372: 425-432, 1994

14. Stephens TW, Basinski M, Bristow PK, et al: The role of neuropeptide $\mathrm{Y}$ in the antiobesity action of the obese gene product Nature 377: 530-532, 1995.
15. Masuzaki H,Ogawa Y, Isse N, et al: Human obese gene expression. Adipocyte-specific expression and regional differences in the adipose tissue. Diabetes 44: 855-888, 1995.

16. Montague CT, Farooqi SI, Whitehead JP, et al: Congenital leptin deficiency is associated with severe early-onset obesity in humans. Nature 387: 903-908, 1997.

17. Considine RV, Sinha MK, Heiman ML, et al: Serum immunoreactive-leptin concentrations in normal-weight and obese humans. New Engl J Med 334: 292-295, 1996.

18. Stenvinkel P, Lonnqvist F and Schalling M: Molecular studies of leptin: implications for renal disease. Nephrol Dial Transplant 14: 1103-1112, 1999.

19. Narkiewicz K, Somers VK, Mos L, Kato M, Accurso V and Palatini P: An independent relationship between plasma leptin and heart rate in untreated patients with essential hypertension. J Hypertens 17: 245-249, 1999.

20. Shek EW, Brands MW and Hall JE: Chronic leptin infusion increases arterial pressure. Hypertension 31: 409-414, 1998.

21. Dunbar JC, Hu Y and Lu H: Intracerebroventricular leptin increases lumber and renal sympathetic nerve activity and blood pressure in normal rats. Diabetes 46: 2040-2043, 1997.

22. Aizawa-Abe M, Ogawa Y, Masuzaki H, et al : Pathophysiological role of leptin in obesity-related hypertension. J Clin Invest 105: 1243-1252, 2000.

23. Suter PM, Locher R, Hasler E and Vetter W: Is there a role for the ob gene product leptin in essential hypertension? Am J Hypertens 11: 1305-1311, 1998.

24. Shintani M, Ikegami H, Yamato E, et al: A novel microsatellite polymorphism in the human OB gene: a highly polymorphic marker for linkage analysis. Diabetologia 39: 1398-1401, 1996.

25. Maestrini S, Mencarelli M, Verti B, et al: Lack of association between the tetranucleotide repeat polymorphism in the 3'-flanking region of the leptin gene and hypertension in severely obese patients. J Endocrinol Invest 29: 776-780, 2006.

26. Gaukrodger N, Mayosi BM, Imrie H, et al: A rare variant of the leptin gene has large effects on blood pressure and carotid intima-medial thickness: a study of 1428 individuals in 248 families. J Med Genet 42: 474-478, 2005.

27. Rutkowski MP, Klanke CA, Su YR, et al: Genetic markers at the leptin (OB) locus are not significantly linked to hypertension in African Americans. Hypertension 31: 1230-1234, 1998.

28. Kuafman JS, Durazo-Arvizu RA, Rotimi CN, McGee DL and Cooper RS: Obesity and hypertension prevalence in populations of African origin. The Investigators of the International Collaborative Study on Hypertension in Blacks. Epidemiology 7: 398-405, 1996.

29. Van Itallie TB: Health implications of overweight and obesity in the United States. Ann Intern Med 103: 983-988, 1985.

30. Jacob CO and Tashman NB: Disruption in the AU motif of the mouse TNF-alpha 3' UTR correlates with reduced TNF production by macrophages in vitro. Nucleic Acids Res 21: 2761-2766, 1993.

31. Misquitta CM, Iyer VR, Werstiuk ES and Grover AK: The role of 3'-untranslated region (3'-UTR) mediated mRNA stability in cardiovascular pathophysiology. Mol Cell Biochem 224: 53-67, 2001.

32. Karvonen MK, Pesonen U, Heinonen P, et al: Identification of new sequence variants in the leptin gene. J Clin Endocrinol Metab 83: 3239-3242, 1998.

33. Schorr U, Blaschke K, Turan S, Distler A and Sharma AM: Relationship between angiotensinogen, leptin and blood pressure levels in young normotensive men. J Hypertens 16: 1475-1480, 1998.

34. Uckaya G, Ozata M, Sonmez A et al: Plasma leptin levels strongly correlate with plasma renin activity in patients with essential hypertension. Horm Metab Res 31: 435-438, 1999.

35. Aubert J, Darimont C, Safonova I, Ailhaud G and Negrel R: Regulation by glucocorticoids of angiotensinogen gene expression and secretion in adipose cells. Biochem J 328: 701-706, 1997.

36. Jones BH, Standridge MK, Taylor JW and Moustaid N: Angiotensinogen gene expression in adipose tissue: analysis of obese models and hormonal and nutritional control. Am J Physiol 273: R236-R242, 1997. 